\title{
A Canadian Paradox: Tommy Douglas and Eugenics
}

\author{
Michael Shevell
}

\begin{abstract}
Tommy Douglas is an icon of Canadian 20th Century political history and is considered by many as the "Father" of Medicare, a key component of our national identity. Throughout his career, he was associated at both the provincial and federal levels with progressive causes concerning disadvantaged populations. In his sociology Master's thesis written in the early 1930's, Douglas endorsed eugenic oriented solutions such as segregation and sterilization to address what was perceived to be an endemic and biologically determined problem. At first glance, this endorsement of eugenics appears to be paradoxical, but careful analysis revealed that this paradox has multiple roots in religion, political belief, historical exposure and our own desire to view our collective history in a favourable light.
\end{abstract}

\begin{abstract}
RÉSUMÉ: Un paradoxe canadien : Tommy Douglas et l'eugénisme. Tommy Douglas est un personnage bien connu de l'histoire politique canadienne du 20e siècle. Il est considéré par plusieurs comme le "Père" du système de santé publique, un élément clé de notre identité nationale. Pendant toute sa carrière, il a été associé aux causes progressistes touchant les couches sociales défavorisées, tant au niveau provincial que fédéral. Dans sa thèse de maîtrise en sociologie rédigée au début des années 1930, Tommy Douglas appuyait les solutions d'orientation eugénique telles la ségrégation et la stérilisation comme solutions à ce qui était perçu comme un problème endémique, à déterminant biologique. De prime abord, cet appui de l'eugénisme semble paradoxal, mais une analyse plus approfondie révèle que ce paradoxe a des ancrages multiples dans la religion, les croyances politiques, le contexte historique et notre propre désir de voir notre histoire collective sous un jour favorable.
\end{abstract}

Can. J. Neurol. Sci. 2012; 39: 35-39

Though bespectacled and slight of build, Thomas Clement (Tommy) Douglas, is a giant of 20th Century Canadian history. ${ }^{1}$ His iconic, indeed mythic, status within the Canadian historical landscape is exemplified by his selection, in 2004, as "The Greatest Canadian" in a CBC mandated competition above such luminaries as former Prime Ministers Pierre Elliot Trudeau and Lester Bowles Pearson, scientist Frederick Banting, and hockey great Wayne Gretzky. ${ }^{2}$ This honor reflects Douglas's own stated lifelong commitment to "helping mankind along the road that leads to social justice and economic emancipation". "From a practical perspective, it reflects his role as the 'father' of Canadian Medicare, which has emerged, for better or worse, as a defining feature of a Canadian national identity. ${ }^{4}$

Medicare's basic principles embody how Canadians wish to both see themselves and distinguish their nation from a powerful, and at times overwhelming, continental neighbour. It has in effect emerged as a statement of national values. Values that include compassion, fairness, tolerance and equality; values that are not selectively applied, but are extended to embrace even the most vulnerable of Canadians. ${ }^{5}$

A consideration or embodiment of such values is missing from the practice of eugenics, which concerns itself at its most fundamental level with the selective breeding of humanity to improve the human species. ${ }^{6}$ At a practical level, eugenics in the twentieth century involved the removal from the gene pool by various means those classes of individuals considered "inferior stock", whose deficits had an inherited basis that was immutable for future generations. These classes included those suffering from mental illness, intellectual disability or what, was characterized as social diseases (e.g, alcoholism, delinquency). Typically eugenics and its actions were directed at individuals with conditions for whom neurologists provide direct specialty care for; epilepsy, intellectual disability, cerebral palsy, progressive neurodegenerative disorders (e.g. Huntington), alcoholism, organic psychoses.

A paradox reflects an apparent contradiction. The broad principles of universal access medicare contradicts those that can be utilized to justify the practice of eugenics. It would be paradoxical for an individual to support both. Yet Tommy Douglas did so with moral persuasion. Careful analysis of this contradiction reveals with hindsight further paradoxes that merit consideration.

From the Department of Neurology/Neurosurgery \& Pediatrics; Division of Pediatric Neurology, Montreal Children's Hospital-McGill University Health Center, Montreal, Quebec, Canada.

Received June 9, 2011. Final Revisions Submitted July 19, 2011. Correspondence to: Michael Shevell, Room A-514, Montreal Children's Hospital, 2300 Tupper, Montreal, Quebec, H3H 1P3, Canada. 


\section{Tommy Douglas- A Brief Biography ${ }^{1,7-10}$}

Tommy Douglas was born in Falkirk, Scotland in 1904. His father was an iron worker and the family emigrated to Winnipeg in 1911, returning to Scotland for the years of World War I before settling in Winnipeg once again 1919. Seminal exposures before adulthood that would chart the path of future endeavours included; 1) Douglas's protracted struggles with osteomyelitis that lead to multiple hospitalizations and the near amputation of a leg prior to the pro bono intervention of a distinguished local orthopedic surgeon, 2) Douglas's mother's active involvement in JS Woodworth's Methodist All People's Church and Mission in the North End that embraced the social gospel (see below), and 3) Douglas's witnessing from a rooftop perch the violent and fatal confrontations of the Winnipeg General Strike of 1919.

Douglas received his college education locally from Brandon College, a Baptist- funded and affiliated institution. Subsequent to graduation, Douglas would take up the pulpit in south-eastern Saskatchewan at the Calvary Baptist Church in Weyburn. His arrival in Weyburn in 1929 coincided with the profound dislocation, both economic and social, of the traditional agrarian and small town ways of the Prairies. In the spirit of the social gospel, Douglas sought active engagement with the community, seeking ways to practically help those in need, both within and outside of his church membership. He thus became involved in the solicitation and distribution of food donations, the organization of the unemployed, and the supervision of wayward youth. He also once again witnessed the violence that could result from labor conflict, this time occurring within the context of the Estevan coal strike of 1931.

Douglas saw little, if any, distinction between his role as a minister and the pursuit of advocacy. His clear and forceful oratorical skills became a staple of provincial United Farmers of Saskatchewan and Independent Labor meetings beginning in 1932. Both of these groups were key constituents in the creation of the Cooperative Commonwealth Federation (CCF) in 1933 that put forward the Regina Manifesto that has as its raison d'être state-guaranteed social and economic rights that were predicated on a centrally planned socialized economy. ${ }^{11}$

Douglas would stand for election as a CCF candidate, first provincially in 1934, and again at the federal level in 1935, whereupon he was elected a Member of Parliament at the age of 31. Within Parliament, together with other CCF members, he would regularly put forward the need for a social safety net that included the protection of vulnerable Canadians and the creation of a publicly funded healthcare network. As a delegate and chaperone to the World Youth Congress of 1936 in Geneva, he would visit both Spain, then embroiled in a Civil War between political extremes, and a Nazi Party rally in Nuremberg. The latter experience would clearly be contributory to his nonpacifist stance with respect to a Canadian Declaration of War, allied to the United Kingdom, in September 1939. Indeed Douglas would join the Second Battalion of the South Saskatchewan Regiment and rise to the rank of Lieutenant. He would seek to join the Winnipeg Grenadiers prior to their disastrous overseas deployment. It is somewhat ironic to note that the early leg problems that were the seed of Douglas's passionate commitment to universal healthcare, was likely also the reason for preserving his life as these difficulties precluded his joining a military unit that would be decimated both in the
Fall of Hong Kong on Christmas Day 1941 and the cruelty of subsequent long-term Japanese captivity.

Douglas returned to provincial politics in 1941 as Leader of the CCF of Saskatchewan. Putting forth a "Plan for Saskatchewan" that advocated economic prosperity through resource development that would be a predicate to a substantive reformation of programs in social services, education and health, he led the CCF to a landslide win (47 of 52 provincial seats) over an indifferent incumbent Liberal administration in 1944. What followed can best be characterized as a whirlwind of legislative and administrative actions which included 76 bills passed in the first month and 196 bills in the first 18 months. A partial list of achievements included; 1) Health Services Act (1944), 2) Health Services Planning Commission (1945), 3) Saskatchewan Bill of Rights (1947), 4) Hospital Services Insurance Act (1947), 5) Public Services Act (1948), 6) Saskatchewan Arts Board (1948), 7) Saskatchewan Mental Health Act (1950), 8) Medical Care Insurance Act (1961). The Hospital Services Insurance Act would lead to the Federal Hospital Insurance and Diagnostic Services Act (1957), and the Medical Care Insurance Act would lead to federally mandated and funded Medicare (1968), together creating the framework of Canadian health services delivery that has endured to the present day.

Following five successive elective majorities between 1944 and 1960, Douglas would return to Federal politics in 1960 as leader of the New Democratic Party, the successor of the CCF. $\mathrm{He}$ would remain at the Federal level taking a lonely stand against the implementation of the War Measures Act in 1970 during the October Crisis. He would resign from public political life in 1979 and die of cancer in 1986.

\section{The Eugenics Context}

Eugenics emerged as a 'science' and philosophical orientation in the late 19 th and early 20 th centuries. ${ }^{6}$ The key drivers in this emergence were the application of Darwinian principles of natural selection to a broad range of social issues, together with a Mendelian understanding of genetics. This coincided with considerable societal unrest that reflected social and economic anxieties brought about by migration, industrialization, urbanization, and the end of imperialism and empire, that was coupled with a profound and ultimately naïve belief in the capacity of science to understand and rectify problems. This enabled a formulation of heredity as the major determinant of behavior, temperament and intelligence. If environmental factors had limited influence and it was understood that "like begets like", then it was conceivable that biology was destiny and potential solutions would be biological in their construction. Eugenics concerned itself with improving breeding (i.e. creating a better human) and within its framework could both identify problems and propose solutions.

These solutions included in North America sterilization laws specifically targeting those with intellectual disability (i.e. "feeble mindedness"), mental illness, and moral degeneracy (i.e. sexual delinquency). ${ }^{12}$ Indiana would be the first state to so legislate in 1907, and by the latter 1920's, twenty-four states had similar legislation that would be found constitutional by the US Supreme Court in the Buck v Bell decision of 1928, in which Justice Oliver Wendall Holmes famously wrote both that "three generations of imbeciles are enough" and "the principle that 
sustains compulsory vaccination is broad enough to cover cutting the Fallopian tubes". ${ }^{13}$ Eugenic rationalizations, principally driven by the fear of immigration diluting the predominantly Anglo-Saxon and Nordic composition of the United States, lay behind the restrictions of a 1924 Immigration Act that would prove a deadly barrier to many trying to flee the impending doom of late 1930's Europe. ${ }^{14}$

Canada was not immune to eugenic enactments. ${ }^{15}$ Both the Alberta (1928) and British Columbia (1933) legislatures passed a Sexual Sterilization Act. These acts were largely based on a 1921 mental hygiene survey of Alberta conducted by a University of Toronto psychiatry professor Clarence Hincks. Hincks identified as a social hardship and a threat to society both the mentally ill and the mentally defective, causally linking these individuals' mental abnormality to immorality. Both provincial acts enabled a Eugenics Board to compel sterilization, if the individual was incompetent, those with mental illness or disability. Review of cases was largely superficial with a decision pre-ordained as witnessed by a $99 \%$ sterilization approval rate by these boards. Furthermore, decisions of these boards were preferentially rendered against females (60\%) and Aboriginals $(6 \%)$ out of proportion to their membership in the population.

Outside of North America, the most nefarious application of eugenic practice and principles was evident in Nazi Germany during the Third Reich. ${ }^{16}$ In April 1933, passage of the "Law for the Prevention of Genetically Diseased Offspring" resulted in the sterilization of over 400,000 individuals, predominantly those with schizophrenia, intellectual disability, or epilepsy. The Nuremberg Race Laws of 1935 applied eugenics to the determination of citizenship, and by extension its protections and privileges, while compelling pre-marital screening of couples. Finally, the creation of the "Committee for the Scientific Treatment of Genetically Determined Illness" and Aktion T-4 in 1939 led to two mass killing programs that not only resulted in the deaths of over 5,000 children and 70,000 adults, but also provided a training ground for the techniques and personnel that would lead to the wholesale slaughter of ethnic groups in Eastern Europe during World War II.

\section{Douglas and Eugenics}

The potential practical utility of eugenics is evident in Douglas's MA thesis. ${ }^{17}$ Undertaken as part of his correspondence degree in sociology, it was submitted in March 1933 to McMaster University. Completed under the supervision of A.L. McCrimmon it bears the title; "The Problems of the Subnormal Family". The thesis reflects both psychology's initial focus on mental and moral concerns and the extension of eugenic influence to the social sciences reframing social problems in terms of a biological understanding, thus prompting the consideration of biological solutions to social ills. The thesis also embodies a faith in experts and trust in agents of the state, who working with the paramount goal of public service would be expected to invariably act humanely and reasonably.

The thesis's focus is on poverty and its key cause as identified by Douglas; 'the subnormal family'. The subnormal family is either mentally or morally inadequate and is characterized by one or more of the following defining features; 1) a low mental rating (i.e. intelligence), 2) moral standards that are below normal, 3) subject to social disease, and 4) a charge on the public purse. The subnormal family is considered "the most appalling of all family problems", one which requires remedies to both initially mitigate and ultimately to remove its burden from within the midsts of society. These dual imperatives to mitigate and remove are mandated by the collective effects of the subnormal family on society. As itemized by Douglas these burdens include; 1) a three fold increase rate of sexually transmitted diseases, 2) a perceptible lowering of community-wide standards of mental and intellectual capability, 3) a similar lowering of collective communal moral standards, and 4) increased economic societal costs with little in the way expected of a satisfactory return for these economic expenditures.

Douglas generates the 'data' for his analysis and recommendations from a detailed study of twelve immoral or non-moral women living in Weyburn. In careful detailed tables and geneologies (i.e. pedigrees), he identifies that the twelve women had 200 descendants over two generations (95 children and 105 grandchildren) of whom 175 are alive, with an equal number of these determined to be 'morally delinquent' (34) or 'normal' (34). Douglas highlights with some alarm that the high birth rate of these individuals (7.9 compared to a local then existing average of 3.1) suggests, with typical eugenic inferences, that without intervention this burden will only increase with subsequent generations.

The combination of the subnormal family's collected burdens on society and the perceived prospect of this burden increasing with time suggests to Douglas that it's the responsibility of the state as the agent of the community to address and alleviate; "the feelings and convenience of the individual should in this matter be subordinated to the good of the State" (page 23). According to Douglas, the principle cause of the subnormal family is heredity, as evident by the vertical transmission across the generations of both mental defect and physical disease. The other causes listed by Douglas (i.e. the filth and squalor of the immediate local environment, the in-group preferential social contacts, and unfavourable economic position) all are derived in a substantial part from the immutable effects of heredity.

To address the effects of heredity most directly Douglas suggests sterilization of those who are either incurably diseased (a term which is never precisely defined) or mentally defective. For Douglas, it is this irreversible action that most aptly meets the requirements of the situation; "surely the continued policy of allowing the subnormal family to bring in to the world large numbers of individuals to fill our jails and mental institutions and to live upon charity is one of consummate folly"(page 6). Douglas minimizes the effects of the removal of individual reproductive choice; "it [sterilization] gives protection to society, yet it deprived the defective of nothing" (page 25) and "sterilization would deprive them of nothing they value very highly" (page 26). In addition to sterilization, Douglas also advocates other eugenic inspired methods including social segregation, the segregation of the sexes, and the use of medical certification attesting to individual mental and physical fitness prior to marriage. Certification, which may preclude the ability to legally enter into a marital union with a chosen partner, is considered by Douglas as something which "should not be too much to ask" (page 21) of limited inconvenience to the parties involved. It is interesting to note that the themes and conclusions 
put forward by Douglas in his MA thesis would be repeated in a Douglas authored 1934 CCF Research Review entitled "Youth and the New Age".

\section{Paradoxes to be Considered}

Douglas's explicit endorsement of a eugenic driven solution (i.e. sterilization) to the problem of the "subnormal family" raises paradoxes to be considered at multiple levels. The first of these concerns is adoption of such an approach given the primacy of Christianity in his lifelong drive and dedication to social reform. For Douglas, social reform was part of God's plan for the improvement of the human condition..$^{8,10}$ Douglas oftstated that his religion was a "practical Christianity" in which there was no distinction between the sacred and the secular; in which action accounted for more than scripture, doctrine or theology. This emphasis was captured in the "social gospel" that provided for the application of the gospel to social conditions with an articulated vision of what might be, thus leading the way to a better future. According to the tenets of the social gospel, a Christian had a duty to engage in social service and reform and ultimately God's judgement would reflect an individual's commitment to others, especially those amongst us who are disadvantaged or oppressed. At first glance, this appears to be at odds with eugenics. However, though rooted in the science of heredity eugenics did draw upon morality and religion to justify beyond the objectivity of science its enactments. Indeed a biological "Golden Rule" was articulated by AE Wiggam; "Do onto both the born and unborn as you would have both the born and unborn do unto you", thus "implying the projection of the Golden Rule down the stream of protoplasm". ${ }^{18}$ The interdigitation of eugenics and religion can also be found in a eugenics sermon contest conducted in 1927 and the American Eugenic Society's pronouncement of a Eugenic Catechism (1926). ${ }^{19}$

A second paradox concerns endorsement of eugenics by a lifelong social democrat. Typically we currently associate eugenics with extreme right wing political movements by recalling the horrific eugenic inspired actions of the Third Reich. At the time of Douglas's Master's Thesis, considerable economic and social tumult was the hallmark of what would be the interwar years. Clearly, unfettered capitalism had failed and the demise of long-standing rigid imperilistic societies had left a vacuum in the setting of societal dislocation on a massive scale. This led to the emergence of radical and extremist political movements on both the right and left of the spectrum. Both shared several beliefs. These included; 1) a belief in massive government involvement in the conduct and reform of society, 2) a belief in science to provide objective solutions that symbiotically aligned to political theory, and finally 3 ) a belief that the way forward (i.e. the means used) would lead to a better future (i.e. the ends) that would provide retrospective justification to whatever actions taken. Douglas was not a lonely socialist in his support of eugenics. He was joined by such international luminaries of leftish opinion as JS Haldane, Sydney and Beatrice Webb, George Bernard Shaw and HG Wells amongst others. ${ }^{6}$

A third paradox lies in Douglas's theoretical endorsement of eugenics and his later actions taken as both Saskatchewan's Minister of Health and Premier. When able to implement action, Douglas did not choose a eugenic path. Indeed the path he followed can be considered a direct contradiction to what would be eugenic principles. In this first term as Saskatchewan's Premier, when he also held the post of Minister of Health, Douglas rejected the recommendations of two reviews of Saskatchewan's mental health system that put forward sterilization of the mentally disabled as a policy option. ${ }^{8}$ Rather he placed an emphasis on therapy and vocational training and expanded by ten-fold the budget of the Psychiatric Branch of the province's Public Health Department during his time as Premier. This robust budgetary expansion led to the physical improvement of facilities, the establishment of a communitybased network for direct care provision, and was concurrent with the implementation of mandated staff qualifications. Similarly, his collective legislative achievements (Health Services Act, Hospital Services Insurance Act, Saskatchewan Mental Health Act, and the Medical Care Insurance Act) effectively removed economic barriers to healthcare access across the range of illness and disability. Finally, the enactment of a provincial Bill of Rights that predated that of the United Nations provided a catalyst to the creation of a culture of tolerance and protection for vulnerable individuals. It has been suggested that Douglas failed to pursue even limited eugenic measures when in power due to his first hand view of Nazi symbolism and power in 1936; "It was frightful. I came back and warned my friends about .... Hitler standing there giving the salute with Goering and rest of the Nazi bigwigs by his side". ${ }^{10}$

A final paradox concerns our collective national amnesia regarding Douglas's initial endorsement of eugenics. ${ }^{1,2}$ When we choose to recall his life and many contributions, this chapter of eugenic endorsements is either omitted ${ }^{2}$ or only briefly and tangentially mentioned. ${ }^{1}$ It is likely that we have transferred onto Douglas the man, those values we attach to his most tangible and enduring achievement, Medicare. As previously stated, these values include compassion, tolerance, fairness, and a pervasive commitment to equality. Similarly, we have attached these values to ourselves and incorporated these values into the matrix that is the Canadian identity. It would be self-defeating of this identity to somehow taint its origins or fountainhead with the lapsed judgements and enactments of eugenics that are by definition directed at the vulnerable, weak and incapacitated amongst us.

\section{Conclusion}

Tommy Douglas briefly held endorsement of a eugenic framework to both understand the overwhelming challenge of poverty in Depression-era Canada and formulate lasting biological solutions is at first glance paradoxical. However, though both mistaken and retrospectively regretful, this endorsement can be seen to stem logically from the overarching themes and principles of social commitment and engagement that fashioned his life of public service. Douglas famously urged Canadians to "dream no little dreams" in their efforts to fashion a modern nation. It is chastening for us to consider in our own time that efforts to solve the social problems facing us may compel possible solutions that at their root may be dangerous compromises with more fundamental and treasured humanistic values. The challenge, as always, will be standing fast to these values despite the temptations of false prophets. 


\section{REFERENCES}

1. Lam V. Tommy Douglas. Toronto: Penguin Group (Canada); 2011.

2. The greatest Canadian. (cited 2011 May 15). Available from: http://en.wikipedia.org/wiki/The_Greatest_Canadian.

3. Douglas TC. Speeches of Tommy Douglas. Ottawa, Ontario: Douglas-Coldwell Foundation.

4. Saul JR. Introduction in: Tommy Douglas. Toronto: Penguin Group (Canada); 2011.

5. Campbell B, Marchulden G. Medicare: facts, myths, problems, promise. Canadian Centre for Policy Alterations: Ottawa; 2007.

6. Kevles DJ. In the name of eugenics: genetics and the uses of human heredity. Berkeley, California: University of California Press; 1985.

7. Johnson AW. Dream no little dreams: a biography of the Douglas Government of Saskatchewan, 1944-1961. Toronto: University of Toronto Press; 2004.

8. McLeod TH, McLeod I. Tommy Douglas: the road to Jerusalem. Calgary: Fifth House; 2004.

9. Stewart W. The life and political times of Tommy Douglas. Toronto: McArthur and Company; 2003.
10. Thomas L. The making of a socialist. The recollections of TC Douglas. Edmonton: University of Alberta Press; 1982.

11. Zakuta L. A protest movement becalmed: a study of the CCF. Toronto: University of Toronto Press; 1964.

12. Ludmerer K. Genetics and American society. Baltimore, Maryland: Johns Hopkins Press; 1972.

13. Buck v Bell 274 US p203 \& 207 (1927).

14. Coolodge C. Whose county is this? Good Housekeeping. February 1921.

15. Mclaren A. Our own master race: eugenics in Canada, 1885-1945. Toronto: McClelland and Stewart; 1990.

16. Proctor RN. Racial hygiene: medicine under the Nazis. Cambridge, Massachusetts: Harvard University Press; 1988.

17. Douglas TC. "The problems of the subnormal family" (1933). Open Access Dissertations and Thesis. Paper 2993 [http://digital commons.mcmaster.ca/opendissertations/2993].

18. Wiggam AE. The new decalogue of science. New York: BobbsMerrill; 1923.

19. American Eugenics Society. A eugenics catechism. 1926. 